\title{
Study of delays in constructions: a managerial point of view of private companies in Brasilia, Brazil
}

\author{
Estudo de atrasos em obras: o ponto de vista do gerenciamento de \\ empresas privadas em Brasilia, Brasil
}

\author{
Eduardo Lavocat Galvão de Almeida ${ }^{1}$ (D), Vitor Amadeu da Silva Feitoza² (D, \\ Michele Tereza Marques Carvalho ${ }^{3}$ (D), Ana Beatriz Souza Piña ${ }^{3}$ (D), Lissa Gomes Araújo ${ }^{3}$ (D), \\ Luiz Augusto Gimenez Aidar ${ }^{3}$ (D) \\ ${ }^{1}$ Universidade Estadual de Campinas, Civil Engineering Graduation Program, Campinas, SP, Brasil. \\ E-mail: eduardolavocat@gmail.com \\ ${ }^{2}$ Instituto Federal de Educação, Ciência e Tecnologia do Tocantins, Campus Palmas, Palmas, TO, Brasil. \\ E-mail: vitorfeitoza@hotmail.com \\ 3Universidade de Brasília, Campus Darcy Ribeiro, Brasília, DF, Brasil. Email: micheletereza@gmail.com; \\ ana.beatriz.souza.pina@gmail.com; lissagomesaraujo@gmail.com; luiz.augusto_aidar@hotmail.com
}

How to cite: Almeida, E. L. G., Feitoza, V. A. S., Carvalho, M. T. M., Piña, A. B. S., Araújo, L. G., Aidar, L. A. G. (2021). Study of delays in constructions: a managerial point of view of private companies in Brasilia, Brazil. Gestão \& Produção, v28(3), e5120. https://doi.org/10.1590/1806-9649-2021v28e5120

\begin{abstract}
Delay is one of the most recurrent problems in the construction industry. It is the cause of major negative consequences on construction projects and it can be the main reason for project failures. Still, there is a need for studies focusing on causes of these delays. The objective of this article is to determine the factors with greatest influence on the backlog of real estate developments, improving the collective list of causes of delays in construction projects. A list of 24 probable causes was assembled and submitted as a survey for 47 professionals in administrative rolls from the building construction sector, more precisely, from private companies. The results were processed utilizing the Relative Importance Index (RII) ranking approach. The outcome shows that the most important delay causes are: rework, poor labor productivity, lack of qualified labor, unqualified labor, and project changes. The results also indicate that there are significant differences of opinion between the professionals of distinct hierarchy positions. The results obtained indicate that there is a transition between the opinions of professionals in different roles regarding the importance of influential factors in the delay of works, according to the managerial level of each group.
\end{abstract}

Keywords: Construction industry; Delay; Influencing factors; Construction projects.

Resumo: Atrasos são um dos problemas mais recorrentes na indústria da construção, causas de consequências negativas em projetos de construção e, muitas vezes, motivo principal de fracassos de projetos. Ainda existe a necessidade de estudar as causas dos atrasos em obras de construção. O objetivo deste trabalho é determinar as causas mais influentes nos atrasos dos projetos de construção civil da indústria privada, colaborando com a lista acadêmica geral das causas dos atrasos na construção civil. Uma lista com 24 causas foi compilada e submetida como questionário para 47 profissionais em papéis administrativos em obras do setor privado da construção. Os resultados foram processados por meio do Índice de Importância Relativa

Received Jan. 21, 2019 - Accepted Dec. 08, 2019

Financial support: We thank the financial support of Conselho Nacional de Desenvolvimento Científico e Tecnológico - CNPq for the development of this work now published.

This is an Open Access article distributed under the terms of the Creative Commons Attribution License, which permits unrestricted use, distribution, and reproduction in any medium, provided the original work is properly cited. 
(Relative Importance Index - RII). As causas mais importantes de atraso foram: retrabalho, baixa produtividade da mão-de-obra, falta de mão-de-obra qualificada, e mudanças de projeto. Os resultados indicam que existem diferenças significativas entre as opiniões dos profissionais de diferentes posições hierárquicas. As contribuições mais significativas desse estudo são que as causas dos atrasos na construção variam dependendo dos profissionais em cada nível hierárquico da obra, demonstrando a importância de entender o problema em prol de uma visão sistêmica e profunda do fenômeno.

Palavras-chave: Indústria da construção; Atrasos; Fatores; Projeto.

\section{Introduction}

The compliance with deadlines in the construction industry is essential for the success of a new structure, from the point of view of the client or regarding the financial expectations of the constructors. Rosenfeld (2014) highlights the importance given to the time goal for the completion of a project. This topic is considered one of the main pillars in accomplishing good results in the construction sector.

Therefore, to plan and to control the deadlines should be a priority, when it comes to the construction management of a new development. Companies employ many methods to control the construction time, however, the complexity involved poses challenges in guaranteeing appropriate results.

The deviations of time are referred to as delays. Delays in a construction project may foment other problems for the parts involved. Mydin et al. (2014) indicated the five most relevant issues, in order of importance: over-budgeting; conflicts of opinions; renegotiations; judicial lawsuits and complete abandonment of the construction.

Construction delays occur frequently on large projects, resulting not only in later completion but also in a major impact on the cost, duration, and quality of the project (Lessing et al., 2017). So, its constant assessment can bring valuable insights, as the industry advances in management techniques and incorporates the appropriate findings in its context.

It is agreed that the delay in construction works is a problem that affects several countries. Al-Momani (2000) published a study where, out of the 130 works evaluated via questionnaire in Jordan, 106 were delayed. Frimpong et al. (2003) verified that 33 of the 47 sample ventures in Ghana were delayed. Assaf \& Al-Hejji (2006) obtained the same proportion for works with deadlines in Saudi Arabia, in the order of $70 \%$ of the total. In a study carried out in Brazil, Feitoza (2014) showed that $46 \%$ of the projects studied were behind schedule. Sambasivan et al. (2017) studied delays in Tanzanian construction industry and pointed out the role of Transaction Cost Economics (TCE) in the construction-industry literature in explaining the impact of causes on effects of delays.

In view of the seriousness and recurrence of the problem, it is important to identify the factors that most influence term extensions, so that delays and their consequences can be avoided and minimized. These factors of influence have been widely studied in the world for years, mainly in developing countries (Toor \& Ogunlana, 2008).

In Brazil, studies on the causes of work delays are scarce (Muianga et al., 2015), which leaves the industry even behind regarding management actions. As an aggravating factor, the country presents different challenges and peculiarities 
in each place due to its continental proportions, which hinders the generalization of results for the different regions of the country.

Broadly, researches focusing on the causes of delay for private construction companies are not common. Usually, publications provide a comparison between public and private sector directly (Eik-Andresen et al., 2016), or analyse the real estate sector from the financial point of view.

In this context, the objective of this article is to determine the factors with the greatest influence on the backlog of real estate developments, improving an evergrowing list of causes of delays in construction projects.

For that, a methodological structure of five steps was employed: [1] An extensive bibliographical review to collect factors that causes delays; [2] From the literature, select the influence factors most adequate to reach the objective of the research; [3] A list of 24 probable causes of the problem assembled and submitted as a survey for 47 professionals in administrative rolls from private construction companies; and [4] Processing the results utilizing the Relative Importance Index (RII) ranking approach. The outcome shows that the most important delay causes are: rework, poor labor productivity, lack of qualified labor, unqualified labor, and project changes. Also, the study identifies the level of influence of factors from the point of view of professionals in different functions among contractors, indicating a significant difference in opinions of professionals of distinct hierarchy positions.

\section{Literature review}

The literature surrounding this theme is extensive. A Systematic Literature Review (SLR) operated in 2014 found 90 articles that present, as themes, the factors that affect the time and cost of constructions (Muianga et al., 2015). Therefore, the five influence factors on the construction delay that appears the most were:

- Shortage of acceptable quality material, inadequate material, poor supply of material, delay in acquisition of imported material - 46 articles;

- Precarious management of the enterprise - 40 articles;

- Financial problems - 35 articles;

- Defects, errors, and omissions in the project - 34 articles;

- Lack of skill and experience of the Construction Company and workers 26 articles.

Summarizing, it is noted that many of the influence factors can converge between different researches. Looking further, De Filippi \& Melhado (2015) point out that there may also be a convergence of results among countries with similar socioeconomic realities, but, in general, these factors are highly dependent on the specific reality of each region.

To represent this diversity, studies from 15 different countries were selected. The most important influence factors and the research characteristics were compared and resumed in Table 1. 
Table 1. Characteristics of the research in 15 correlated articles.

\begin{tabular}{|c|c|c|c|c|c|}
\hline Author & Country & $\begin{array}{c}\text { Number } \\
\text { of } \\
\text { Factors }\end{array}$ & $\begin{array}{l}\text { Most important } \\
\text { factor of the } \\
\text { research }\end{array}$ & $\begin{array}{l}\text { Method of } \\
\text { Analysis }\end{array}$ & $\begin{array}{c}\text { Sample } \\
\text { Size }\end{array}$ \\
\hline $\begin{array}{l}\text { Fugar \& } \\
\text { Agyakwah-Baah } \\
(2010)\end{array}$ & Ghana & 32 & Delay on payments & RII & 130 \\
\hline Naoum (2016) & & 46 & $\begin{array}{l}\text { Inefficient project } \\
\text { planning in the pre- } \\
\text { construction phase }\end{array}$ & RII & 36 \\
\hline $\begin{array}{l}\text { Doloi et al. } \\
\text { (2012) }\end{array}$ & India & 45 & Lack of commitment & RII & 77 \\
\hline $\begin{array}{l}\text { Sambasivan e } \\
\text { Soon (2007) }\end{array}$ & Malaysia & 28 & $\begin{array}{c}\text { Precarious } \\
\text { management from } \\
\text { the constructor }\end{array}$ & RII & 150 \\
\hline $\begin{array}{l}\text { Aiyetan et al. } \\
\text { (2011) }\end{array}$ & South Africa & 7 & $\begin{array}{l}\text { Construction planning } \\
\text { and control } \\
\text { techniques }\end{array}$ & Mean Score & 112 \\
\hline $\begin{array}{l}\text { Kaming et al. } \\
\text { (1997) }\end{array}$ & Indonesia & 11 & $\begin{array}{l}\text { Changes in the } \\
\text { project }\end{array}$ & Severity index & 31 \\
\hline Lo et al. (2006) & $\begin{array}{c}\text { China (Hong } \\
\text { Kong) }\end{array}$ & 30 & $\begin{array}{l}\text { Inadequate facilities } \\
\text { or financial difficulties } \\
\text { of the constructor }\end{array}$ & $\begin{array}{l}\text { Overall Mean } \\
\text { Score }\end{array}$ & 158 \\
\hline $\begin{array}{l}\text { Gardezi et al. } \\
(2014)\end{array}$ & Pakistan & 27 & $\begin{array}{l}\text { Legal and order } \\
\text { matters }\end{array}$ & RII & 50 \\
\hline $\begin{array}{l}\text { Kazaz et al. } \\
(2012)\end{array}$ & Turkey & 34 & $\begin{array}{l}\text { Changes in the } \\
\text { materials of the } \\
\text { project }\end{array}$ & RII & 71 \\
\hline $\begin{array}{l}\text { Aibinu \& } \\
\text { Odeyinka (2006) }\end{array}$ & Nigeria & 44 & $\begin{array}{l}\text { Financial difficulties of } \\
\text { the constructor }\end{array}$ & RII & 102 \\
\hline $\begin{array}{l}\text { Toor and } \\
\text { Ogunlana (2008) }\end{array}$ & Thailand & 75 & $\begin{array}{l}\text { Lack of standard in } \\
\text { the projects }\end{array}$ & Mean Score & 76 \\
\hline $\begin{array}{l}\text { Mezher \& Tawil } \\
\text { (1998) }\end{array}$ & Lebanon & 64 & $\begin{array}{l}\text { Financing and } \\
\text { outsourcing schedule, } \\
\text { contractual relations } \\
\text { and project changes, } \\
\text { inadequate planning. }\end{array}$ & $\begin{array}{l}\text { Importance } \\
\text { Index }\end{array}$ & 36 \\
\hline $\begin{array}{l}\text { Faridi \& El- } \\
\text { Sayegh (2006) }\end{array}$ & $\begin{array}{c}\text { Arab } \\
\text { Emirates }\end{array}$ & 44 & $\begin{array}{l}\text { Inadequate initial } \\
\text { planning of project } \\
\text { and delay in project } \\
\text { preparation and } \\
\text { approval }\end{array}$ & RII & 93 \\
\hline $\begin{array}{l}\text { Assaf \& Al-Hejij } \\
(2006)\end{array}$ & Saudi Arabia & 73 & $\begin{array}{l}\text { Change of requests } \\
\text { from the contractor } \\
\text { during the } \\
\text { construction process }\end{array}$ & $\begin{array}{l}\text { Severity, } \\
\text { Frequency e } \\
\text { Importance } \\
\text { Index }\end{array}$ & 54 \\
\hline $\begin{array}{l}\text { Sweis et al. } \\
(2008)\end{array}$ & Jordanian & 91 & $\begin{array}{l}\text { Financial difficulties of } \\
\text { the constructor and } \\
\text { changes in the } \\
\text { projects }\end{array}$ & $\begin{array}{l}\text { Drewin's Open } \\
\text { Conversion } \\
\text { System }\end{array}$ & 40 \\
\hline $\begin{array}{l}\text { Le-Hoai et al. } \\
\text { (2008) }\end{array}$ & Vietnam & 87 & $\begin{array}{l}\text { Lack of supervision } \\
\text { and management of } \\
\text { the construction site }\end{array}$ & $\begin{array}{l}\text { Severity, } \\
\text { Frequency e } \\
\text { Importance } \\
\text { Index }\end{array}$ & 21 \\
\hline
\end{tabular}

Source: Authors.

It can be noticed that most of the studies were conducted in Africa and Asia, with very little responses from the international literature on the situation in Latin America. 
Muianga et al. (2015) corroborate with this perception by indicating that only $1 \%$ of the articles that adheres to this theme are from South America, while $80 \%$ are related to Africa and Asia. This amplifies the need for studies in this region of the globe.

In addition, there is a great variation among the most influential factors between countries, yet the set of factors studied belong to a limited universe. Greater factors are related to inefficient planning or management (Naoum, (2016); Sambasivan \& Soon, (2007); Aiyetan et al., (2011); Mezher \& Tawil, (1998); Faridi \& El-Sayegh (2006); LeHoai et al. (2008)). Also, another main factor that appears on these studies are related to financial problems (Sweis et al., (2008); Mezher \& Tawil, (1998); Aibinu \& Odeyink, (2006); Lo et al., (2006)).

Among the methods of analysis of the influence factors for these studies, the RII method, or Relative Importance Index, which will also be used in this document, stands out, corroborating to its use in further studies.

In a new research carried out from 2014 to 2016, three recently published articles were found. De Filippi \& Melhado (2015) led a study focused on real estate developments in the metropolitan region of São Paulo. In the research, 32 constructions were included in the survey that resulted in the ranking of the factors that appeared most frequently. Those factors are poor management or supervision (staff organization) at the construction site, interference of subcontractors or inadequate work, delays in the work of subcontractors (or third parties), and labor shortage (labor supply). Finally, Reis et al. (2016) presented the result of a survey conducted with 61 construction professionals from the metropolitan area of Belém. In the 56 factors surveyed, the ones that obtained the highest frequency among those that had influence in the emergence of time deviations were delayed in materials delivery, rework due to errors during construction, lack of commitment from workers, and delay in materials delivery, and the inefficiency of the purchasing sector.

Because they have different niches, a distinction can be made among the influence factors between studies carried out in São Paulo and Minas Gerais, even though these belong to the same region. Regardless, in the case of municipal buildings, the factors are more related to the public contracting method; in the case of real estate projects, the main factors are more related to the management of constructions sites. These three studies, and also the lack of it except on the last two years, shows an evident knowledge gap and a need to characterize such market facing international parameters, in an effort to improve the industry on academic and economic standards. Even with many international researchers, it is important to find the connection with the context of the projects and the factors that can cause delays, and this study seeks to contribute to this connection.

\section{Research methodology}

The work structure was developed and divided into 5 stages: a bibliographic review, the definition of influence factors, survey, data processing and result analysis.

\subsection{Phase 1}

At first, an extensive bibliographical research was carried out, with the theme of influence factors or delay causes in construction works. The databases consulted were: Scopus, Web of Science Core, Compendex, SciELO and InfoHab. The terms used were: construction, delay, time overrun, factors and causes and their respective terms 
in Portuguese. More than 80 articles of conferences and magazines were found directly from the research using the snowball technique. Public university repositories and the CAPES dissertation bank were also consulted with the purpose of compiling dissertations and published theses.

\subsection{Phase 2}

From the literature, the influence factors most adequate to reach the objective of the research were selected. Since, as stated earlier, the importance of factors varies greatly from place to place, the list of 24 factors proposed by Feitoza (2014), the closest to the context of the study, was the point of departure for comparison with the factors collected from the literature, to reach the final list used in this study. These factors were grouped into four groups, namely: manpower, management, project and external factors.

\subsection{Phase 3}

The survey was carried out with 47 professionals from 40 private companies in the construction field of vertical commercial and residential buildings of medium to high standards, all operating in the private market in Brasilia - Federal District - Brazil. The structured questionnaire applied contained information from the professionals interviewed, the private companies where they worked and the importance of factors in the delay of works.

\subsection{Phase 4}

At this stage, the data acquired from the survey were processed. For this, the Relative Importance Index (RII) was chosen. As reported, this technique was used in previous studies (Kazaz et al., 2012; Jarkas \& Bitar, 2012). This index (RII) can be calculated for each of the factors using Equation 1:

$\operatorname{RII}(\%)=\frac{4(\mathrm{n} 4)+3(\mathrm{n} 3)+2(\mathrm{n} 2)+\mathrm{n} 1}{4(\mathrm{n} 4+\mathrm{n} 3+\mathrm{n} 2+\mathrm{n} 1)} \times 100$

The terms n1, n2, n3, and n4 are, respectively, the number of respondents who answered 1 for minimal influence, 2 for weak influence, 3 for strong influence and 4 for maximum influence on the delay of works. The RII values found for each factor were used to create an orderly ranking from the most to least influential factor.

At the time of the questionnaire, respondents were asked to bestow a number from 1 to 4 for each factor, taking into account the scale of influence above.

Two other methods were used to analyse the correlations between the positions of the professionals with the factors pointed out, aiming to identify the influence of each point of view.

The first method used is the Spearman Correlation Coefficient. This method calculates the monotonic correlation between responses by positions using, for this, the placements of each factor (Abd El-Razek et al., 2008). A monotonic correlation indicates a tendency of increase or decrease between variables, but not necessarily in a proportional way. Other studies use the same method to measure the level of agreement between different parties (Alwi \& Hampson, 2003; Assaf et al., 1995). This coefficient is calculated using the Equation 2, given by Assaf \& Al-Hejji (2006). 
Spearman Correlation Coefficient $=1-\frac{6 x \sum \mathrm{d}^{2}}{\left(\mathrm{n}^{3}-\mathrm{n}\right)}$

In this equation, $d$ is the difference between the placement of a factor between the ranks of professionals of different positions and $\mathrm{n}$ is the number of factors. The coefficient value goes from +1 (means a perfect correlation) to -1 (perfect negative correlation). The value 0 (zero) denotes no correlation between the results.

The second method that complements the analysis is the Pearson Correlation Coefficient. This coefficient measures the linear correlation between RII coefficients of two-part factors in the case of two groups of professionals, which means that it can indicate proportional increase or decrease between two variables. The calculation method can be seen below in Equation 3 .

$$
\text { Pearson Correlation Coefficient }=\frac{\mathrm{n}\left(\sum \mathrm{xy}\right)-\left(\sum \mathrm{x}\right)\left(\sum \mathrm{y}\right)}{\sqrt{\left(\mathrm{n} \sum \mathrm{x}^{2}-\left(\sum \mathrm{x}\right)^{2}\right)\left(\mathrm{n} \sum \mathrm{y}^{2}-\left(\sum \mathrm{y}\right)^{2}\right)}}
$$

The comparison between Spearman and Pearson can indicate greater tendencies to monotonic correlation than linearity or vice versa, but low correlations not necessarily indicate no correlations, only that they can not be linear or monotonic.

As in the Spearman method, $n$ corresponds to the number of factors. $X$ and $Y$ are the RII factor values for two groups of professionals. To verify the statistical significance, the calculation of the $p$-value for the relations is also performed, known as the descriptive level of relations or probability that have null value. The evaluation method in this research is calculated for a $95 \%$ confidence level. This means that any result with a p-value above 0.05 should be discarded for its lack of reliability.

\subsection{Phase 5}

With the data treatment, the analysis and discussion of the results with previous works were performed. In a second moment, the result is analysed as to the correlation of the interviewees' opinions when grouped by their functions.

\section{Results and analysis}

The population of this research consists of private companies in the residential and commercial vertical construction in Brasilia - Federal District. The full list of companies in this specialized market was acquired from phone books and direct information from the union (Sindicato da Indústria da Construção Civil - Sinduscon - DF), totalizing 129 companies. The size of the sample was calculated according to Stevenson (1981), resulting in 41 companies. The first approach to contact these companies was thought their listed specialized professional. 51 professionals answered to an in person interview, when the questionnaires were applied.

Regarding the companies of the sample, $63,7 \%$ had more than 30 years of experience and $46 \%$ were considered of medium size regarding the number of employers. $39 \%$ of them were executing more than four projects at the time of the interview, and $76 \%$ had some type of quality certification. 
Table 2 presents interviewees' information on the function and experience. This study tried to portrait a maximum of the type of professionals involved, so, the sample contains five professionals: directors, supervisors, project managers, field managers and resident managers. The biggest percentage according to experience was found in the ' 6 to 10 years' category, showing the youth of the industry in Brazil.

Table 2. Experience and function of the interviewees.

\begin{tabular}{|c|c|c|c|c|c|c|}
\hline \multirow{2}{*}{ Function } & \multirow{2}{*}{$\begin{array}{c}\text { Number of } \\
\text { interviewees }\end{array}$} & \multicolumn{5}{|c|}{ Experience (years) } \\
\hline & & 0 a 5 & 6 a 10 & 11 a 15 & 16 a 20 & $>20$ \\
\hline Director & 2 & $0 \%$ & $50 \%$ & $0 \%$ & $50 \%$ & $0 \%$ \\
\hline Supervisor & 7 & $0 \%$ & $57 \%$ & $29 \%$ & $0 \%$ & $14 \%$ \\
\hline Project Manager & 2 & $0 \%$ & $0 \%$ & $0 \%$ & $0 \%$ & $100 \%$ \\
\hline Field Manager & 21 & $5 \%$ & $38 \%$ & $10 \%$ & $14 \%$ & $33 \%$ \\
\hline Resident Engineer & 15 & $80 \%$ & $13 \%$ & $7 \%$ & $0 \%$ & $0 \%$ \\
\hline Total & 47 & $27 \%$ & $32 \%$ & $11 \%$ & $9 \%$ & $21 \%$ \\
\hline
\end{tabular}

Source: Authors

The main product of this article is summarized in Table 3 . The 24 influence factors are classified in descending order regarding the importance given by the professionals of the field.

Table 3. Classification of the influence factors by RII

\begin{tabular}{|c|c|c|c|}
\hline Classification & Influence Factors & RII & Group \\
\hline 1 & Rework & $75.0 \%$ & Manpower \\
\hline 2 & Low labor productivity & $73.0 \%$ & Manpower \\
\hline 3 & Lack of skilled labor & $72.5 \%$ & Manpower \\
\hline 4 & Low qualification of labor & $70.5 \%$ & Manpower \\
\hline 5 & Modifications to the project & $69.5 \%$ & Project \\
\hline 6 & Failure to manage deadlines & $69.0 \%$ & Management \\
\hline 6 & Poor specification or lack of definition of the project & $69.0 \%$ & Project \\
\hline 8 & Incompatibility of projects & $67.0 \%$ & Project \\
\hline 9 & Poor qualification in the contractor's technical staff & $65.0 \%$ & Manpower \\
\hline 9 & Delay in delivery of material & $65.0 \%$ & Management \\
\hline 11 & Unrealistic schedule & $64.0 \%$ & Management \\
\hline 12 & Timing failures due to overestimation of productivity & $63.0 \%$ & Management \\
\hline 13 & Delay in ordering materials & $61.5 \%$ & Management \\
\hline 14 & Conflict between parties (contractor and contractor) & $61.0 \%$ & Management \\
\hline 15 & $\begin{array}{l}\text { Delay in delivery of material at the front of service } \\
\text { (handling at the construction site) }\end{array}$ & $59.0 \%$ & Management \\
\hline 16 & Delay in the mobilization of the work & $52.0 \%$ & Management \\
\hline 17 & Low efficiency and productivity of equipment & $51.0 \%$ & External Factors \\
\hline 18 & Delay for defective material & $48.5 \%$ & External Factors \\
\hline 19 & Effects of climate on construction (heat, rain) & $47.5 \%$ & External Factors \\
\hline 20 & Equipment shortage & $45.5 \%$ & External Factors \\
\hline 20 & Accident during construction & $45.5 \%$ & External Factors \\
\hline 22 & Complexity of the project & $44.4 \%$ & Project \\
\hline 23 & Scarcity of building materials on the market & $43.5 \%$ & External Factors \\
\hline 24 & Equipment defects & $41.5 \%$ & External Factors \\
\hline
\end{tabular}

Source: Authors. 
The top factor of the list is rework. In most cases, rework means the allocation of labor in activities that have already been performed, resulting in a loss of the work sequence, a decrease in service teams and a decrease in productivity. Rework can also happen due to change orders, which are changes in the scope of the activity agreed, to solve a problem or to please a new aesthetic desire of the client. Regarding similar results, Gündüz et al. (2013) study in Turkey is enlightening. In the article, the authors indicate that the rework reaches a value of $74.7 \%$ of RII, corroborating to the overall picture of concern regarding this specific factor. If rework is motivated by errors of the execution, this cause should be a concern of the company and be further investigated. If it happens to please a desire of the final client, the company should have measures to avoid material loss in this case.

Coming second in the ranking is the factor of low labor productivity. The low productivity of services and products results in the need for a longer production time or a larger contingent of workers. Labor productivity is another richly researched term, and part of a continuous work seeking for the factors that affect it itself, and specifically when related to delays, it appears in studies carried out in Brazil (Filippi \& Melhado, 2015; Reis et al., 2016), Kaming et al. (1997) in Indonesia, Toor \& Ogunlana (2008) in Thailand, Faridi \& El-Sayegh (2006) in the United Arab Emirates and Kazaz et al. (2012) in Turkey.

The shortage of skilled labor and low labor qualification are ranked as third and fourth places in the table, respectively. It reveals the existence of a shortage of trained professionals with qualified technical knowledge, which, according to the interviewees, culminates in a serious influence on the term extension. A similar result is obtained by Filippi \& Melhado, 2015, who ranked the labor shortage factor in third, and by Gündüz et al. (2013), who ranked the low qualification and inexperience of the workforce as the eighth factor. Reis et al. (2016) classify this very item outside the top 15 , which suggests that this is a less worrying situation in the city of Belém.

Note that the first four factors in the list are linked to labor. This paradigm represents the reality experienced by the sector, which is labor-intensive (Yi \& Chan, 2014) and the difficulties faced by the managers of works in front of a problem that is rooted in the civil construction industry.

Continuing the analysis, the project modifications factor was placed in the fifth position. With $69.5 \%$ RII, this factor is considered important, since project modifications change the initial conditions on which the planning was based and, applying to this theme, the elaborated schedule. Depending on the size and the timing of the project modification, a complete re-evaluation of the construction schedule is required. Thus, this factor is also well cited in the literature, being listed by many authors, such as Lo et al. (2006), Sweis et al. (2008), Koushki et al. (2005) and Kaliba et al. (2009).

Tied in the sixth position, there are the failures in managing deadlines and the poor specification or lack of project definition. The first indicates the direct influence that the work management has on the control and management of deadlines. Errors practiced by professionals responsible for these functions reflect negatively in the construction term. And the second factor, that a poor specification or a lack of design can inevitably result in a project being delayed due to changes in the initial design conditions, resulting in rework.

A similar problem is caused by the factor in the eighth position. The incompatibility of projects is still a concern for the sector. Despite the existence of technologies that already considerably reduce the intensity and frequency of occurrences of this phenomenon, as is the case of BIM technologies (Eastman et al., 2011), companies and professionals are still resistant to adhere to these solutions, which implies in inconsistencies identified too late, leading to design modifications that often involve rework. 
In the ninth place, the factors are poor qualification in the technical staff of the contractor and delay in delivery of material. The first is another one that joins the group of factors related to the workforce. The other is the first of the factors in the ranking related to materials that influence the term extension. Abd El-Razek et al. (2008) is one study that presents this factor among the 10 most influential, with Egypt as a country of study.

The non-realistic timeline factor is the 11 th place with $64 \%$ RII. The obvious problem caused by a failure to execute the schedule results in this position of great relevance, although not among the 10 most influential. On the other hand, comparing with the case reported by Toor \& Ogunlana (2008) in Thailand, where this factor reaches the 5th position among 75 factors, we can assume that the intensity of this problem in Brazil is not the greatest one found in the scarce bibliography.

One of the possible reasons for the occurrence of this reality leak can be explained by the next factor in the list, the schedule failures due to the overestimation of productivity and/or the failures of the production planning and control model based on the critical path method. In the 12th position, this factor has its origins in the lack of data information on productivity and/or in the "optimism" of the professional who produces the schedule in the most efficient execution of the services. Being one or the other, or even the product of the two, the result is precisely the unrealistic schedule factor.

In 13th there is the delay in the request for materials, a factor that is directly related to the management of the work. The literature shows that this is another relevant influence factor in other parts of the world. The management of materials, in this case represented by the delay of requests, is a problem reported in Malaysia (Sambasivan \& Soon, 2007), in the United Arab Emirates (Faridi \& El-Sayegh, 2006), UK (Sullivan \& Harris, 1986), Turkey (Arditi et al., 1985), among others.

Next, in the 14th position, the last factor listed above the $60 \%$ RII, the conflict between the parties (contractor and contracted). This factor is observed, given the type of contract, because the contractor and contracted have divergent interests. This aspect of risk imbalance and culture of adversity among the stakeholders in a venture is one of the main factors responsible for most of the performance problems in the industry. Several surveys, such as Leung et al. (2004) emphasize the urgency of shifting the relationship standards among stakeholders in the industry towards collaboration, trust, and balanced risk sharing, which often lead to friction between parties that can result in significant delays. Abd El-Razek et al. (2008) cite the factor in the study elaborated in Egypt. In the article, the authors show that the factor is little relevant for the term extension, and, in this research, the result is moderately influential.

The other factors, placed below the $60 \%$ RII line, showed little influence to the professionals interviewed.

Table 4 presents the classification according to the groups of factors.

Table 4. Classification of groups of factors by RII

\begin{tabular}{ccc}
\hline Classification & Group & RII \\
\hline 1 & Manpower & $71.2 \%$ \\
\hline 2 & Project & $62.6 \%$ \\
\hline 3 & Management & $61.8 \%$ \\
\hline 4 & External Factors & $46.2 \%$ \\
\hline
\end{tabular}

Source: Authors. 
First, the group of labor-related factors appears. With RII expressively higher than the other three groups, it is concluded that, in general, professionals link more expressively the problem of delay in works with this group of factors.

In second and third place, the groups of design and project management factors are present. With RII around $60 \%$, the two groups are of moderate general importance. And the last group, of external factors, does not have as much importance in the term extension.

\subsection{Correlations of opinion by the use of functions}

Table 5 brings together, for comparison purposes, the five main influential delay factors in works for professionals, grouped by their functions.

Table 5. Five main influence factors by interviewees' functions.

\begin{tabular}{|c|c|c|c|c|}
\hline Director & Supervisor & Project Manager & Field Manager & $\begin{array}{l}\text { Resident } \\
\text { Engineer }\end{array}$ \\
\hline Rework & $\begin{array}{l}\text { Low qualification } \\
\text { of labor }\end{array}$ & Rework & $\begin{array}{c}\text { Failure to manage } \\
\text { deadlines }\end{array}$ & $\begin{array}{l}\text { Poor specification } \\
\text { or lack of definition } \\
\text { of the project }\end{array}$ \\
\hline $\begin{array}{l}\text { Lack of skilled } \\
\text { labor }\end{array}$ & $\begin{array}{l}\text { Low labor } \\
\text { productivity }\end{array}$ & $\begin{array}{l}\text { Low labor } \\
\text { productivity }\end{array}$ & $\begin{array}{l}\text { Poor specification } \\
\text { or lack of definition } \\
\text { of the project }\end{array}$ & $\begin{array}{l}\text { Modifications to } \\
\text { the project }\end{array}$ \\
\hline $\begin{array}{l}\text { Low labor } \\
\text { productivity }\end{array}$ & $\begin{array}{l}\text { Lack of skilled } \\
\text { labor }\end{array}$ & $\begin{array}{l}\text { Modifications to } \\
\text { the project }\end{array}$ & Rework & Rework \\
\hline $\begin{array}{l}\text { Low qualification } \\
\text { of labor }\end{array}$ & $\begin{array}{l}\text { Low efficiency and } \\
\text { productivity of } \\
\text { equipment }\end{array}$ & $\begin{array}{l}\text { Incompatibility of } \\
\text { projects }\end{array}$ & $\begin{array}{l}\text { Incompatibility of } \\
\text { projects }\end{array}$ & $\begin{array}{l}\text { Low labor } \\
\text { productivity }\end{array}$ \\
\hline $\begin{array}{l}\text { Delay in delivery } \\
\text { of material at the } \\
\text { front of service }\end{array}$ & Rework & $\begin{array}{l}\text { Delay in delivery } \\
\text { of material at the } \\
\text { front of service }\end{array}$ & $\begin{array}{l}\text { Unrealistic } \\
\text { schedule }\end{array}$ & $\begin{array}{l}\text { Low qualification } \\
\text { of labor }\end{array}$ \\
\hline
\end{tabular}

Source: Authors.

From Table 5, it can be seen that, other than the project managers, the other professionals did not diverge much from the general result shown in Table 3. For the project managers, management and project management factors were more important than those of labor, going against the opinion of the other interviewees. It should also be noted that the rework factor is present among the 5 most important in the five cases, the only one among the 24 factors.

To deepen the discussion about how the professionals with different functions in construction companies think, the result correlation study was carried out to measure the level of correspondence between the opinions of the interviewees. Table 6 shows the results of the Spearman's rank correlation coefficient method.

Table 6. Spearman's rank correlation coefficient by interviewees' functions.

\begin{tabular}{cccccc}
\hline SPEARMAN & Director & Supervisor & $\begin{array}{c}\text { Project } \\
\text { Manager }\end{array}$ & $\begin{array}{c}\text { Field } \\
\text { Manager }\end{array}$ & $\begin{array}{c}\text { Resident } \\
\text { Engineer }\end{array}$ \\
\hline Director & 1 & & & & \\
\hline Supervisor & 0.51 & 1 & & & \\
\hline Project Manager & 0.73 & 0.43 & 1 & & \\
\hline Field Manager & 0.49 & 0.39 & 0.66 & 1 & 1 \\
\hline Resident Engineer & 0.52 & 0.52 & 0.68 & 0.79 &
\end{tabular}

Source: Authors. 
Among the coefficients, the correlation between work managers and resident engineers is higher than Spearman's coefficients, as a result of the interaction and the closer vision among the professionals, since they are directly linked in the hierarchy and in proximity to the most operational aspects within a company.

The correlations between the project manager - construction manager and project manager - and resident engineer are also noteworthy. With relevant values ( 0.66 and 0.68 , respectively), it is understood that the project manager's view is close to that of the professionals with more contact with the operational level. On the other hand, with 0.73 for the Spearman's coefficient, project manager and director have more closely correlated opinions.

These results indicate that the professionals in the position of project manager have an intermediary opinion among the professionals of the strategic level, the director, and the professionals at the operational level, in the case of the other two.

Table 7 shows the results of the Pearson correlation coefficient method.

Table 7. Pearson correlation coefficient by interviewees' functions.

\begin{tabular}{cccccc}
\hline PEARSON & Director & Supervisor & $\begin{array}{c}\text { Project } \\
\text { Manager }\end{array}$ & $\begin{array}{c}\text { Field } \\
\text { Manager }\end{array}$ & $\begin{array}{c}\text { Resident } \\
\text { Engineer }\end{array}$ \\
\hline Director & 1 & & & & \\
\hline Supervisor & 0.50 & 1 & & & \\
\hline Project Manager & 0.71 & 0.40 & 1 & & \\
\hline Field Manager & 0.48 & 0.38 & 0.65 & 1 & 1 \\
\hline Resident Engineer & 0.51 & 0.52 & 0.67 & 0.79 & 1 \\
\hline
\end{tabular}

Source: Authors.

Note that the numbers are very close to those found in the Spearman method, which confirms that data is linearly and strongly correlated. On the other hand, the relationship between supervisor - project manager and supervisor - and work manager, in this case, did not reach a minimum p-value in order to be considered, and these were discarded from evaluation.

The results presented in Tables 6 and 7 indicate that there is a transition between the opinions of professionals in different roles regarding the importance of influential factors in the delay of works, according to the managerial level of each group. This finding is important for a better understanding of the opinion of the interviewees regarding their role within private companies. The influence of such visions was already addressed in previous studies (AI Nasseri \& Aulin, 2016; Ojelabi et al., 2017), as a means to show a dependency between hierarchy and decision making and problem envision.

The two proposed methods were followed by previous studies that dealt with the level of correspondence between opinions among different parties.

Abd El-Razek et al. (2008) gathered a list of causes of delay in the construction industry of Egypt, with special attention to the responses of each type of professional involved in a construction project. Not only the authors separated the responses according to contractors, consultants, and owners, but they also divided the causes into groups according to the responsibility of each delay, with a fourth group for common responsibility. In order to mitigate the delays, they said, it is important to identify the responsibility for it. The final ranking was a tie of responsibilities between the contractor and the owner, showing that the mitigation must come from a team effort. Also, the correlation was low between the index of contractors and owners but was high 
between the consultant's opinions and the other two groups, showing that the consultant has a more impartial point of view regarding delays and responsibilities.

Mahamid et al. (2012) also tested the accordance of top causes of delays between contractors and consultants when applying its questionnaires to map the Palestinian construction industry. In this case, the accordance was of $75 \%$, attesting to the reliability of the findings.

Rosenfeld (2014) expanded the group of professionals studied, analyzing the correlation of responses from designers, owners, project managers, consultants, and contractors. The highest correlation found was between project managers and overall respondents, showing that these professionals hold a more impartial view of cost overrun root-causes.

These studies show the importance to attribute responsibilities to the diverse problems found in a construction project, and also, how the professionals involved can influence the work with their vision of the causes, depending on the hierarchy and the context of the project.

\section{Conclusions}

Work-time deviation is a worldwide problem and requires special attention since it triggers a number of undesirable consequences for the parties involved. The aim of this article was to determine the factors with greatest influence on the backlog of real estate developments, improving the collective list of causes of delays in construction projects. This objective was achieved with the presentation of a chart with the factors, from highest to lowest influence. This structure has the intention of facilitating the choice of actions that result in the mitigation or prevention of work delays as efficiently as possible.

The results were processed utilizing the Relative Importance Index (RII) ranking approach. The outcome shows that the most important delay causes are: rework, poor labor productivity, lack of qualified labor, unqualified labor, and project changes.

In the case studied of private companies in Brasilia, it is necessary to pay attention to factors related to the workforce. Professional profiling indicates that the quality, productivity, and availability of workers can be a catalyst for future problems with the stipulated schedule. The importance of investing in the training of professionals is verified.

The results obtained indicate that there is a transition between the opinions of professionals in different roles regarding the importance of influential factors in the delay of works, according to the managerial level of each group. This finding is important for a better understanding of the opinion of the interviewees regarding their role within companies. Further studies comparing different understandings between operational and managerial levels surrounding factors that cause delays within the same company are encouraged. This type of analysis would explain the divergence of views among practitioners and promote a more efficient problem-solving.

\section{References}

Abd El-Razek, M. E., Bassioni, H. A., \& Mobarak, A. M. (2008). Causes of delay in building construction projects in Egypt. Journal of Construction Engineering and Management, 134(11), 831-841. http://dx.doi.org/10.1061/(ASCE)0733-9364(2008)134:11(831).

Aibinu, A. A., \& Odeyink, H. A. (2006). Construction delays and their causative factors in Nigeria. Journal of Construction Engineering and Management, 132(7), 667-677. http://dx.doi.org/10.1061/(ASCE)0733-9364(2006)132:7(667). 
Aiyetan, A., Smallwood, J., \& Shakantu, W. (2011). A systems thinking approach to eliminate delays on building construction projects in South Africa. Acta Structilia, 18(2), 19-39.

Al Nasseri, H., \& Aulin, R. (2016). Understanding management roles and organisational behaviour in planning and scheduling based on construction projects in Oman. Journal of Construction in Developing Countries, 21(1), 1-18. http://dx.doi.org/10.21315/jcdc2016.21.1.1.

Al-Momani, A. H. (2000). Construction delay: a quantitative analysis. International Journal of Project Management, 18(1), 51-59. http://dx.doi.org/10.1016/S0263-7863(98)00060-X.

Alwi, S., \& Hampson, K. D. (2003). "Identifying the important causes of delays in building construction projects." In Proceedings East Asia-Pacific Conference on Structural Engineering and Construction, Bali, Indonesia, pp. 16-18.

Arditi, D., Akan, G. T., \& Gurdamar, S. (1985). Reasons for delays in public projects in Turkey. Construction Management and Economics, 3(2), 171-181. http://dx.doi.org/10.1080/01446198500000013.

Assaf, S. A., \& Al-Heji, S. (2006). Causes of delay in large construction projects. International Journal of Project Management, 24(4), 349-357. http://dx.doi.org/10.1016/j.jproman.2005.11.010.

Assaf, S. A., Al-Khalil, M., \& Al-Hazmi, M. (1995). Causes of delay in large building construction projects. Journal of Management Engineering, 11(2), 45-50. http://dx.doi.org/10.1061/(ASCE)0742597X(1995)11:2(45).

Doloi, H., Sawhney, A., lyer, K. C., \& Rentala, S. (2012). Analysing factors affecting delays in Indian construction projects. International Journal of Project Management, 30(4), 479-489. http://dx.doi.org/10.1016/j.jproman.2011.10.004.

Eastman, C., Teicholz, P., Sacks, R., \& Liston, K. (2011). BIM Handbook: a guide to building information modeling for owners, managers, designers, engineers, and contractors (2nd ed.). Hoboken: John Wiley \& Sons, Inc.

Eik-Andresen, P., Landmark, A. D., Hajikazemi, S., Johansen, A., \& Andersen, B. (2016). Remedies for managing bottlenecks and time thieves in Norwegian construction projects public vs private sector. Procedia: Social and Behavioral Sciences, 226(1), 343-350. http://dx.doi.org/10.1016/j.sbspro.2016.06.197.

Faridi, A. S., \& El-Sayegh, S. M. (2006). Significant factors causing delay in the UAE construction industry. Construction Management and Economics, 24(11), 1167-1176. http://dx.doi.org/10.1080/01446190600827033.

Feitoza, V. A. S. (2014). Influência do sistema de gestão de produtividade no custo e prazo de execução dos empreendimentos do Distrito Federal (Maters dissertation). Universidade de Brasília, Brasília. http://dx.doi.org/10.26512/2014.11.D.18880.

Filippi, G. A. D., \& Melhado, S. B. (2015). Um estudo sobre as causas de atrasos de obras de empreendimentos imobiliários na região Metropolitana de São Paulo. Ambiente Construido, 15(3), 161-173. http://dx.doi.org/10.1590/s1678-86212015000300033.

Frimpong, Y., Oluwoye, J., \& Crawford, L. (2003). Causes of delay and cost overruns in construction of groundwater projects in developing countries: Ghana as a case study. International Journal of Project Management, 21(5), 321-326. http://dx.doi.org/10.1016/S0263-7863(02)00055-8.

Fugar, F. D. K., \& Agyakwah-Baah, A. B. (2010). Delays in building construction projects in Ghana. The Australasian Journal of Construction Economics and Building, 10(1), 103-116. http://dx.doi.org/10.5130/ajceb.v10i1/2.1592.

Gardezi, S. S. S., Manarvi, I. A., \& Gardezi, S. J. S. (2014). Time extension factors in construction industry of Pakistan. Procedia Engineering, 77(1), 196-204. http://dx.doi.org/10.1016/j.proeng.2014.07.022.

Gündüz, M., Nielsen, Y., \& Özdemir, M. (2013). Quantification of delay factors using the relative importance index for construction projects in Turkey. Journal of Management Engineering, 29(2), 133-139. http://dx.doi.org/10.1061/(ASCE)ME.1943-5479.0000129. 
Jarkas, A. M., \& Bitar, C. G. (2012). Factors affecting construction labor productivity in Kuwait. Journal of Construction Engineering and Management, 138(7), 811-820. http://dx.doi.org/10.1061/(ASCE)CO.1943-7862.0000501.

Kaliba, C., Muya, M., \& Mumba, K. (2009). Cost escalation and schedule delays in road construction projects in Zambia. International Journal of Project Management, 27(5), 522531. http://dx.doi.org/10.1016/j.jpproman.2008.07.003.

Kaming, P. F., Olomolaiye, P. O., Holt, G. D., \& Harris, F. C. (1997). Factors influencing construction time and cost overruns on high-rise projects in Indonesia. Construction Management and Economics, 15(1), 83-94. http://dx.doi.org/10.1080/014461997373132.

Kazaz, A., Ulubeyli, S., \& Tuncbilekli, N. A. (2012). Causes of delays in construction projects in Turkey. Journal of Civil Engineering and Management, 18(3), 426-435. http://dx.doi.org/10.3846/13923730.2012.698913.

Koushki, P. A., Al-Rashid, K., \& Kartam, N. (2005). Delays and cost increases in the construction of private residential projects in Kuwait. Construction Management and Economics, 23(3), 285-294. http://dx.doi.org/10.1080/0144619042000326710.

Le-Hoai, L., Lee, Y. D., \& Lee, J. Y. (2008). Delay and cost overruns in Vietnam large construction projects: a comparison with other selected countries. KSCE Journal of Civil Engineering, 12(6), 367-377. http://dx.doi.org/10.1007/s12205-008-0367-7.

Lessing, B., Thurnell, D., \& Durdyev, S. (2017). Main factors causing delays in large construction projects: evidence from New Zealand. Journal of Management, Economics, and Industrial Organization, 1(2), 63-82. http://dx.doi.org/10.31039/jomeino.2017.1.2.5.

Leung, M. Y., Chong, A., Ng, S. T., \& Cheung, M. C. (2004). Demystifying stakeholders' commitment and its impacts on construction projects. Construction Management and Economics, 22(7), 701-715. http://dx.doi.org/10.1080/0144619042000300736.

Lo, T. Y., Fung, I. W. H., \& Tung, K. C. F. (2006). Construction delays in Hong Kong civil engineering projects. Journal of Construction Engineering and Management, 132(6), 636649. http://dx.doi.org/10.1061/(ASCE)0733-9364(2006)132:6(636).

Mahamid, I., Bruland, A., \& Dmaidi, N. (2012). Causes of delay in road construction projects. Journal of Management Engineering, 28(3), 300-310. http://dx.doi.org/10.1061/(ASCE)ME.1943-5479.0000096.

Mezher, T. M., \& Tawil, W. (1998). Causes of delays in the construction industry in Lebanon. Engineering, Construction, and Architectural Management, 5(3), 252-260. http://dx.doi.org/10.1108/eb021079.

Muianga, E. A. D., Granja, A. D., \& Ruiz, J. de A. (2015). Desvios de custos e prazos em empreendimentos da construção civil: categorização e fatores de influência. Ambiente Construído, 15(1), 79-97. http://dx.doi.org/10.1590/S1678-86212015000100008.

Mydin, M. A. O., Sani, N. M., Taib, M., \& Alias, N. M. (2014). Imperative causes of delays in construction projects from developers' outlook. MATEC Web of Conferences, 10(1), 1-6, http://dx.doi.org/10.1051/matecconf/20141006005.

Naoum, S. G. (2016). Factors influencing labor productivity on construction sites: A state-of-theart literature review and a survey. International Journal of Productivity and Performance Management, 65(3), 401-421. http://dx.doi.org/10.1108//JPPM-03-2015-0045.

Ojelabi, R. A., Oyeyipo, O. O., \& Afolabi, A. (2017). Built environment professionals' perceptions of the effectiveness of building control measures in Lagos state. Journal of Construction in Developing Countries, 22(1), 41-54. http://dx.doi.org/10.21315/jcdc2017.22.1.3.

Reis, C. J. L., Seixas, R. M., Silva, G. B., Maués, L. M. F., \& Duarte, A. A. A. M. (2016). Identificação das causas de atrasos de obras: um estudo de caso na região metropolitana de Belém. In Proceedings Encontro Nacional de Tecnologia do Ambiente Construído (pp. 21-23). São Paulo: ENTAC. 
Rosenfeld, Y. (2014). Root-cause analysis of construction-cost overruns. Journal of Construction Engineering and Management, 140(1), 04013039. http://dx.doi.org/10.1061/(ASCE)CO.1943-7862.0000789.

Sambasivan, M., \& Soon, Y. W. (2007). Causes and effects of delays in Malaysian construction industry. International Journal of Project Management, 25(5), 517-526. http://dx.doi.org/10.1016/j.jpproman.2006.11.007.

Sambasivan, M., Deepak, T. J., Salim, A. N., \& Ponniah, V. (2017). Analysis of delays in Tanzanian construction industry: transaction cost economics (TCE) and structural equation modelling (SEM) approach. Engineering, Construction, and Architectural Management, 24(2), 308-325. http://dx.doi.org/10.1108/ECAM-09-2015-0145.

Stevenson, W.J. (1981). Estatística aplicada à administração. São Paulo: Harper e Row do Brasil.

Sullivan, A., \& Harris, F. C. (1986). Delays on large construction projects. International Journal of Operations \& Production Management, 6(1), 25-33. http://dx.doi.org/10.1108/eb054752.

Sweis, G., Sweis, R., Abu Hammad, A., \& Shboul, A. (2008). Delays in construction projects: the case of Jordan. International Journal of Project Management, 14(3), 665-674. http://dx.doi.org/10.1016/j.jproman.2007.09.009.

Toor, S., \& Ogunlana, S. O. (2008). Problems causing delays in major construction projects in Thailand. Construction Management and Economics, 26(4), 395-408. http://dx.doi.org/10.1080/01446190801905406.

Yi, W., \& Chan, P. C. (2014). Critical review of labor productivity research in construction journals. Journal of Management Engineering, 30(2), 214-225. http://dx.doi.org/10.1061/(ASCE)ME.1943-5479.0000194. 